\title{
New records of spiders (Aranei) from the Russian Arctic
}

\section{Новые находки пауков (Aranei) в Российской Арктике}

\author{
A.V. Tanasevitch \\ A.B. Танасевич \\ A.N. Severtsov Institute of Ecology and Evolution, Russian Academy of Sciences, Leninsky prospekt, 33, Moscow 119071, Russia. \\ E-mail: tanasevitch@gmail.com \\ Институт проблем экологии и эволюции РАН им. А.Н. Северцова, Ленинский проспект 33, Москва 119071, Россия.
}

KEY WORDS: Russia, spiders, new records, tundra, chorology.

КЛЮЧЕВЫЕ СЛОВА: Россия, пауки, новые находки, тундра, хорология.

ABSTRACT. New records of 34 spider species from the Russian Arctic are presented and supplied with detailed descriptions of their habitats. Some misidentifications are corrected, the known patterns of distribution of many species are complemented and newly typified.

РЕЗЮМЕ. Приведены новые находки 34 видов пауков в Российской Арктике, сопровождённые подробным описанием местообитаний. Исправлены ошибочные определения, известные ареалы многих видов существенно расширены и заново типизированы.

\section{Introduction}

Over the last decade, interest in Arctic spider systematics and distribution has significantly increased. Previous publications mostly contained either lists of spider records from the tundra or descriptions of new tundra-dwelling species [e.g. Eskov, 1985; Eskov, Marusik, 1994; Marusik et al., 1992, 1993; Marusik, Eskov, 2009; Marusik et al., 2016, etc.]. Recent papers deal with species lists of local faunas or particular areas, with analyses of spider distributions in various landscape and vegetation types [e.g. Marusik et al., 2016; Tanasevitch, Koponen, 2007; Tanasevitch, Rybalov, 2010, 2015; Tanasevitch, Nekhaeva 2016; etc.] Extensive information and accurate labeling accompanying the records is often very important for analyzing spider distributions in natural zones or subzones.

In this paper, new records of spiders from the tundra of Russia's Eurasia are given, supplied with detailed habitat descriptions.

\section{Material and methods}

The current paper is largely based on material collected in the Russian Arctic by Anatoly B. Babenko in 1993, 1994 and 2015; additional samples were taken by Yuri I. Chernov (1990, 1993), Valery I. Bulavintsev
\& Nadezhda M. Poryadina (1985), Sonya B. Rozenfeld and Dmitry Nizovtsev (2016). All material is stored in the Zoological Museum of the Moscow State University, Moscow, Russia.

All spiders were collected from the different subzones of the tundra belt of Russia's Eurasia. According to the subzonal differentiation of the tundra zone [Matveeva, 1998], the localities (see Map) are allocated as follows: the southern tundra subzone, No. 2; the typical tundra subzone, Nos 1, 3, 4, 13, 15, 16, 19-21, and the arctic tundra subzone, Nos $5,7,8,11,12,14$, 17, 18. Localities $6,9 \& 10$ lie at the border between the typical and arctic tundras.

The patterns of spider distribution (range) also consider the data contained in the recent publications by Marusik et al. [2016], Tanasevitch \& Rybalov [2015] and Tanasevitch \& Nekhaeva [2016].

In the Material section, the numbers of localities are put in square brackets, sample numbers of A. Babenko are in parentheses.

\section{List of species}

Fam. Gnaphosidae

Micaria constricta Emerton, 1894

MATERIAL. 1 ○’, 3 우 (labeled as M. eltoni Jackson, 1922), Krasnoyarsk Area, Taymyrsky Dolgano-Nenetsky District, Taymyr Peninsula, Lake Taymyr, bank of Postoyannaya River [13], meadow communities, 23.VII.1993, leg. Y. Chernov \& A. Babenko.

REMARKS. In the Taymyr Peninsula, this species has hitherto been recorded from near Lake Pyasina [Osipov, 2003, labeled as M. eltoni].

RANGE. Holarctic arcto-boreal.

Fam. Linyphiidae

Agyneta maritima (Emerton, 1919)

MATERIAL. $1 \sigma^{7}$, Yamalo-Nenets Autonomous Okrug, Yamal Peninsula, env. of Sabetta [6], anthropogenic Gramineae asso- 


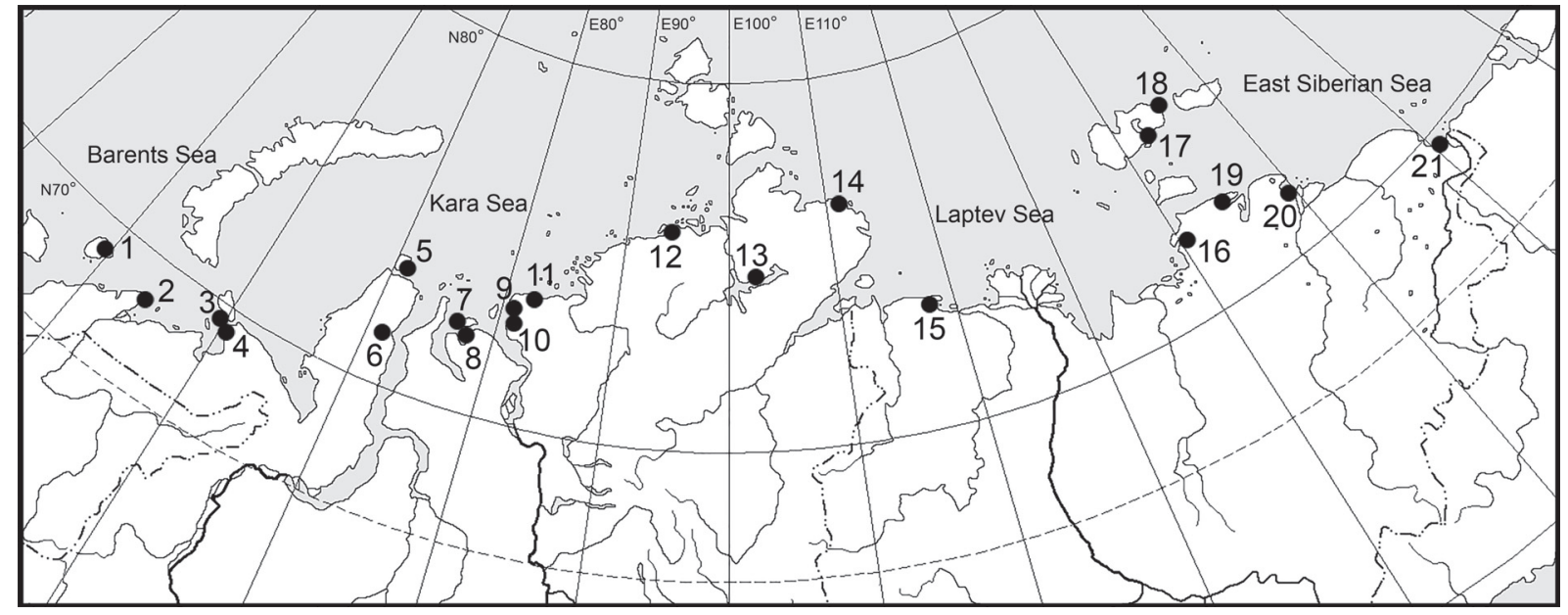

Map. Localities in the Russian Arctic. 1 - Kolguev Island, Lake Goltsovoe $\left(69^{\circ} 12^{\prime} \mathrm{N} 49^{\circ} 30^{\prime} \mathrm{E}\right)$; 2 - Pechora River Bay, Lake Kuznetskoye $\left(68^{\circ} 50^{\prime} \mathrm{N} 53^{\circ} 45^{\prime} \mathrm{E}\right) ; 3$ - Vaygach Island, Varnek $\left(69.69233^{\circ} \mathrm{N} 60.16689^{\circ} \mathrm{E}\right)$; 4 - Yugorsky Peninsula, Belyi Nos, $\left(69.61671^{\circ} \mathrm{N} 60.23250^{\circ} \mathrm{E}\right) ; 5$ - Belyi Island $\left(73.410^{\circ} \mathrm{N} 70.402^{\circ} \mathrm{E}\right) ; 6$ - Yamal Peninsula, Sabetta $\left(71.205333^{\circ} \mathrm{N} 71.870333^{\circ} \mathrm{E}\right) ; 7-$ Oleniy Island $\left(72.30562^{\circ} \mathrm{N} 77.06228^{\circ} \mathrm{E}\right) ; 8$ - northern coast of Gydan Peninsula $\left(72.19228^{\circ} \mathrm{N} 77.57839^{\circ} \mathrm{E}\right)$; 9 - Efremova River flow (ca. $\left.73^{\circ} 11^{\prime} \mathrm{N} 80^{\circ} 54^{\prime} \mathrm{E}\right) ; 10$ - Ragozinka River flow (ca. $\left.72^{\circ} 43^{\prime} \mathrm{N} 80^{\circ} 53^{\prime} \mathrm{E}\right) ; 11$ - Uboynaya River flow (ca. $\left.73^{\circ} 36^{\prime} \mathrm{N} 82^{\circ} 24^{\prime} \mathrm{E}\right) ; 12$ Middendorff Bay, Opalovaya River flow (7556 $\left.{ }^{\prime} \mathrm{N} 94^{\circ} 13^{\prime} \mathrm{E}\right)$; 13 — Lake Taymyr, Ozhidaniya Bay (ca. $\left.74^{\circ} 36^{\prime} \mathrm{N} 101^{\circ} 44^{\prime} \mathrm{E}\right), \mathrm{Cape}^{\circ} \mathrm{Blizhiy}$ (ca. $74^{\circ} 38^{\prime} \mathrm{N} 102^{\circ} 28^{\prime} \mathrm{E}$ ) and Postoyannaya River (ca. $\left.74^{\circ} 37^{\prime} \mathrm{N} 102^{\circ} 45^{\prime} \mathrm{E}\right) ; 14$ - Faddey Land, Rybnaya River flow $\left(76^{\circ} 38^{\prime} \mathrm{N} 111^{\circ} 00^{\prime} \mathrm{E}\right)$; 15 - Olenyok Bay, Lake Vaganytta-Kyuel $\left(73^{\circ} 30^{\prime} \mathrm{N} 118^{\circ} 10^{\prime} \mathrm{E}\right) ; 16$ - Shirokostan Peninsula, Lake Ledyanoye $\left(72^{\circ} 25^{\prime} \mathrm{N} 141^{\circ} 00^{\prime} \mathrm{E}\right)$; 17 - Kotelny Island, Balyktakh River flow ( $\left.75^{\circ} 03^{\prime} \mathrm{N} 140^{\circ} 10^{\prime} \mathrm{E}\right) ; 18$ - Faddey Island, Ulakhan-Uryakh River flow $\left(75^{\circ} 35^{\prime} \mathrm{N} 144^{\circ} 50^{\prime} \mathrm{E}\right)$; 19 - Omulyakhskaya Bay (ca. $\left.72^{\circ} 14^{\prime} \mathrm{N} 145^{\circ} 9^{\prime} \mathrm{E}\right) ; 20$ - Indigirka River Delta $\left(71^{\circ} 26^{\prime} \mathrm{N} 149^{\circ} 45^{\prime} \mathrm{E}\right)$; 21 - Kolyma River Delta, Pokhodskaya Yedoma $\left(69^{\circ} 32^{\prime} \mathrm{N} 160^{\circ} 44^{\prime} \mathrm{E}\right)$.

Карта. Точки сборов в Российской Арктике. 1 - о-в Колгуев, оз. Гольцовое (69² $\left.12^{\prime} \mathrm{N} 49^{\circ} 30^{\prime} \mathrm{E}\right) ; 2$ - Печорская губа, оз. Кузнецкое $\left(68^{\circ} 50^{\prime} \mathrm{N} 53^{\circ} 45^{\prime} \mathrm{E}\right) ; 3$ - о-в Вайгач, Варнек $\left(69.69233^{\circ} \mathrm{N} 60.16689^{\circ} \mathrm{E}\right) ; 4$ - п-ов Югорский, Белый Нос $\left(69.61671^{\circ} \mathrm{N}\right.$ $\left.60.23250^{\circ} \mathrm{E}\right) ; 5$ - о-в Белый $\left(73.410^{\circ} \mathrm{N} 70.402^{\circ} \mathrm{E}\right) ; 6$ - п-ов Ямал, Сабетта $\left(71.205333^{\circ} \mathrm{N} 71.870333^{\circ} \mathrm{E}\right) ; 7$ - о-в Олений $\left(72.30562^{\circ} \mathrm{N}\right.$ $\left.77.06228^{\circ} \mathrm{E}\right) ; 8$ - побережье п-ова Гыдан $\left(72.19228^{\circ} \mathrm{N} 77.57839^{\circ} \mathrm{E}\right) ; 9$ - р. Ефремова (са. $\left.73^{\circ} 11^{\prime} \mathrm{N} 80^{\circ} 54^{\prime} \mathrm{E}\right) ; 10-$ p. Рагозинка $($ са. $\left.72^{\circ} 43^{\prime} \mathrm{N} 80^{\circ} 53^{\prime} \mathrm{E}\right) ; 11$ - р. Убойная (са. $\left.73^{\circ} 36^{\prime} \mathrm{N} 82^{\circ} 24^{\prime} \mathrm{E}\right) ; 12$ - залив Миддендорфа, р. Опаловая $\left(75^{\circ} 56^{\prime} \mathrm{N} 94^{\circ} 13^{\prime} \mathrm{E}\right) ; 13$ - оз. Таймыр, залив Ожидания $\left(74^{\circ} 36^{\prime} \mathrm{N} 101^{\circ} 44^{\prime} \mathrm{E}\right)$, мыс Ближний (са. $\left.74^{\circ} 38^{\prime} \mathrm{N} 102^{\circ} 28^{\prime} \mathrm{E}\right)$ и р. Постоянная (са. $\left.74^{\circ} 37^{\prime} \mathrm{N} 102^{\circ} 45^{\prime} \mathrm{E}\right) ; 14-$ Земля Фаддея, р. Рыбная $\left(76^{\circ} 38^{\prime} \mathrm{N} 111^{\circ} 00^{\prime} \mathrm{E}\right) ; 15$ - залив Оленёкский, оз. Ваганытта-Куел $\left(73^{\circ} 30^{\prime} \mathrm{N} 118^{\circ} 10^{\prime} \mathrm{E}\right) ; 16-\Pi_{-}{ }^{\circ}$ Широкостан, оз. Ледяное $\left(72^{\circ} 25^{\prime} \mathrm{N} 141^{\circ} 00^{\prime} \mathrm{E}\right) ; 17$ - о-в Котельный, р. Балыктах $\left(75^{\circ} 03^{\prime} \mathrm{N} 140^{\circ} 10^{\prime} \mathrm{E}\right) ; 18$ - о-в Фаддея, р. УлаханУрях $\left(75^{\circ} 35^{\prime} \mathrm{N} 144^{\circ} 50^{\prime} \mathrm{E}\right) ; 19$ - Омуляхская губа (са. $\left.72^{\circ} 14^{\prime} \mathrm{N} 145^{\circ} 9^{\prime} \mathrm{E}\right) ; 20$ - дельта р. Индигирки $\left(71^{\circ} 26^{\prime} \mathrm{N} 149^{\circ} 45^{\prime} \mathrm{E}\right) ; 21$ -

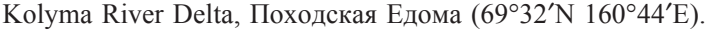

ciations with Poa arctica \& Alopecurus alpinum in undershrub tundra, 28.VII.2015, leg. L. Rybalov; 1 \% , 1 \% (labeled as $A$. nigripes (Simon, 1884)), 1 \%, 1 ( (labeled as Agyneta sp.), Krasnoyarsk Area, Taymyrsky Dolgano-Nenetsky District, Taymyr Peninsula, Lake Taymyr, bank of Postoyannaya River [13], meadow communities, 23.VII.1993, leg. Y. Chernov \& A. Babenko.

REMARKS. This species is recorded from the Taymyr and Yamal peninsulas for the first time. The westernmost locality of the known species distribution lies in the environs of Vorkuta City, Komi Republic [Tanasevitch, Koponen, 2007].

RANGE. Siberian-Nearctic arcto-alpine.

Agyneta mossica (Schikora, 1993)

MATERIAL. 2 OP, Arkhangelsk Area, Nenets Autonomous Okrug, Malozemelskaya tundra, western coast of Pechora River Bay, env. of Lake Kuznetskoye [2], small-hummocky tundra, under driftwood, 25-26.VIII.1994, leg. A. Babenko (R-113/94); 2 $\sigma^{\Upsilon \top} \sigma^{\top}$, same locality, small-hummocky tundra, pitfall traps, 2526.VIII.1994, leg. A. Babenko (R-118/94).

REMARKS. Lake Kuznetskoye is the northernmost locality of the species in the European mainland tundras.

RANGE. West Palaearctic boreo-nemoral.

\section{Bathyphantes humilis (L. Koch, 1879)}

MATERIAL. 1 \% , Arkhangelsk Area, Nenets Autonomous Okrug, Vaygach Island, env. of Varnek Village [3], seashore, under driftwood, 25-26.VIII.1994, leg. A. Babenko (R-07/15).

REMARKS. This species is new to the fauna of the Vaygach Island.

RANGE. Siberian arcto-boreal.

\section{Diplocephalus barbiger (Roewer, 1955)}

MATERIAL. 1 , Arkhangelsk Area, Nenets Autonomous Okrug, Vaygach Island, env. of Varnek Village [3], seashore, under driftwood, 25-26.VIII.1994, leg. A. Babenko (R-06/15); 8 ○ $\sigma^{\top} \&$ + 9 , Yamalo-Nenets Autonomous Okrug, Taz District, northern coast of Gydan Peninsula [8], seashore marsh with Carex subspathacea, Puccinellia phryganodes, pitfall traps, 13-18.VII.2016, leg. S. Rozenfeld; 1 O, Krasnoyarsk Area, Taymyrsky DolganoNenetsky District, NW of Taymyr Peninsula, Ragozinka River flow [10], landslip, bare ground, pitfall traps, 8.VIII.1993, leg. Y. Chernov \& A. Babenko.

REMARKS. This species is new to the fauna of the Gydan Peninsula.

RANGE. Siberian-Nearctic arctic. 
Erigone arctica palaearctica Brændegaard, 1934

MATERIAL. $9 \bigcirc^{\top} \bigcirc^{\top} \&$ \& , Yamalo-Nenets Autonomous Okrug, Taz District, Kara Sea, Belyi Island [5], seashore marsh, pitfall traps, 26.VII-1.VIII.2016, leg. D. Nizovtsev; $113 \sigma^{\top} \sigma^{\top} \&$ \&O+ Taz District, northern coast of Gydan Peninsula [8], seashore marsh with Carex subspathacea, Puccinellia phryganodes, pitfall traps, 13-18.VII.2016, leg. S. Rozenfeld; $111 \sigma^{7} \sigma^{7} \&$ 우, Taz District, Oleniy Island [7], seashore marsh with Carex subspathacea, Puccinellia phryganodes, rare: Cochlearia groenlandica, Hippurus tetraphyla, Senecio congestus, Eriophorum russeolum, pitfall traps, 13-18.VII.2016, leg. S. Rozenfeld.

REMARKS. This (sub?)species is new to the fauna of the Gydan Peninsula.

RANGE. East European arctic.

\section{Erigone arctica sibirica Kulczyński, 1908}

MATERIAL. 1 q, Yakutia Republic, Laptev Sea coast, Olenyok Bay, Lake Vaganytta-Kyuel [15], permafrost hummocks on beach, Dryas communities with Salix polaris, 6-8.VII.1994, leg. A. Babenko (R-1/94); 3 +o, same date and locality, Dryas communities on slope near snow patch, leg. A. Babenko (R-3/94); 1 \% , 2 우, same locality, on snow, 6-8.VII.1994, leg. A. Babenko (R-4/ 94); 1 , same locality, dwarf willow-moss community on slope, pitfall traps, 6-8.VII.1994, leg. A. Babenko (R-11/94).

REMARKS. Lake Vaganytta-Kyuel is the northernmost locality of the known (sub?)species distribution in Yakutia's mainland.

RANGE. Siberian arcto-boreal.

\section{Erigone psychrophila Thorell, 1872}

MATERIAL. $3 \sigma^{\top} \sigma^{\top}, 1$, Krasnoyarsk Area, Taymyrsky Dolgano-Nenetsky District, northern coast of Taymyr Peninsula, Middendorff Bay, Opalovaya River flow [12], spotted tundra, pitfall traps, 15-17.VIII.1994, leg. A. Babenko (R-100/94); $1 \sigma^{7}$, same locality, wet bare ground below snow patch, pitfall traps, 1517.VIII.1994, leg. A. Babenko (R-99/94); 1 \%', NE of Taymyr Peninsula, Faddey Land, Rybnaya River flow [14], zonal type of tundra, pitfall traps, 10-11.VIII.1994, leg. A. Babenko (R-85/94); 1 , Yakutia Republic, Laptev Sea coast, Olenyok Bay, Lake Vaganytta-Kyuel [15], Dryas communities on slope near snow patch, 6-8.VII.1994, leg. A. Babenko (R-3/94); 1 9, same date and locality, on snow, leg. A. Babenko (R-4/94); 2 ㅇ, same locality, in wet hollow, 6-8.VII.1994, leg. A. Babenko (R-5/94); 9 कo , 17 juv., same date and locality, Dryas communities on slope, leg. A. Babenko (R-12/94); 1 フ , 1 + subad., New Siberian Islands, Kotelny Island, Balyktakh River flow [17], bird "canteen" on permafrost hummock, 31.VII.-2.VIII.1994, leg. A. Babenko (R-61/94); 2 +9, same date and locality, Bunge Land, in moss, leg. A. Babenko (R63/94); $2 \sigma^{7} \sigma^{7}, 5$ OO, same date \& locality, hills, brook valley below snow patch, leg. A. Babenko (R-65/94); 1 \%', New Siberian Islands, Faddey Island, Ulakhan-Uryakh River flow [18], wet ground on slope with Luzula nivalis tussocks, 10-11.VII.1994, leg. A. Babenko (R-19/94); $1 \sigma^{7}$, same date and locality, beach with Puccinella, leg. A. Babenko (R-21/94); 1 , same date and locality, zonal type of tundra, pitfall traps, leg. A. Babenko (R-25/94); $1 \mathrm{O}^{7}$, same date and locality, dwarf willow-sedge-moss swamp, sweeping, leg. A. Babenko (R-31/94); 2 우, Yana River Delta, Shirokostan Peninsula, Lake Ledyanoye [16], dwarf willow-Dryas-sedge tundra communities on rock outcrops, 4-6.VIII.1994, leg. A. Babenko (R-72/ 94); 1 ऽ , 4 우, same date and locality, bank of lake, polygonal hollow in peatbogs, pitfall traps, leg. A. Babenko (R-77/94).

REMARKS. Faddey Land is the northernmost locality of the known species distribution in the Taymyr Peninsula.

RANGE. Holarctic arctic.

\section{Erigone remota L. Koch, 1869}

MATERIAL. 2 우, Arkhangelsk Area, Nenets Autonomous Okrug, Malozemelskaya tundra, western coast of Pechora River Bay, env. of Lake Kuznetskoye [2], wet meadow with Calamagrostis deschampsiodes, 25-26.VIII.1994, leg. A. Babenko (R-117/ 94); 3 우, same date and locality, small-hummocky tundra, pitfall traps, leg. A. Babenko (R-118/94).

REMARKS. Lake Kuznetskoye is the northernmost locality of the known species distribution in the European mainland tundras.

RANGE. Palaearctic arcto-alpine.

Erigone tirolensis L. Koch, 1872

MATERIAL. $2 \sigma^{\top} \sigma^{\top}$, Yakutia Republic, East Siberian Sea coast, Indigirka River Delta, Russko-Ustinskaya river branch [20], bank of river, Salix arctophila communities, pitfall traps, 1416.VII.1994, leg. A. Babenko (R-38/94); 1 +, Kolyma Bay, Kolyma River Delta, Pokhodskaya Yedoma [21], under stones at foot of permafrost hummock, 18-19.VII.1994, leg. A. Babenko (R-48/ 94); 1 \%, same date and locality, bank of lake, leg. A. Babenko (R51/94).

REMARKS. In Arctic Yakutia, E. tirolensis has recently been registered from the Kharaulakh Mountains [Tanasevitch, Nekhaeva, 2016].

RANGE. Holarctic arcto-alpine.

\section{Gibothorax tchernovi Eskov, 1989}

MATERIAL. 3 O $^{\top}, 2$, 2 , Yamalo-Nenets Autonomous Okrug, Taz District, northern coast of Gydan Peninsula [8], seashore marsh with Carex subspathacea, Puccinellia phryganodes, pitfall traps, 13-18.VII.2016, leg. S. Rozenfeld.

REMARKS. This species is new to the fauna of the Gydan Peninsula.

RANGE. Siberian arctic.

Halorates boreus (L. Koch, 1879)

MATERIAL. 4 ㅇ, Krasnoyarsk Area, Taymyrsky DolganoNenetsky District, NW of Taymyr Peninsula, Efremova River flow [9], brook bank, under stones, 21.VII.1990, leg. Y. Chernov \& A. Babenko.

REMARKS. In the Taymyr Peninsula, this species has hitherto been known from Lake Syradasai [Eskov, 1985, as Collinsia b.] and Lake Pyasino [Osipov, 2003, as Collinsia b.].

RANGE. Siberian-Alaskan arcto-boreal.

\section{Halorates spetsbergensis (Thorell, 1872)}

MATERIAL. $1 \sigma^{r}, 1$, Krasnoyarsk Area, Taymyrsky Dolgano-Nenetsky District, northern coast of Taymyr Peninsula, Middendorff Bay, Opalovaya River flow [12], under stones near water, 15-17.VIII. 1994, leg. A. Babenko (R-97/94); 1 ㅇ, Lake Taymyr, Ozhidaniya Bay [13], wet bare ground below snow patch, pitfall traps, 18.VII.1993, leg. A. Babenko (L-15/93).

REMARKS. Middendorff Bay is the northernmost locality of the known species distribution in the Taymyr Peninsula.

RANGE. Holarctic arctic.

\section{Hilaira gertschi Holm, 1960}

MATERIAL. $2 \sigma^{7} \sigma^{7}$ (labeled as H. nivalis Holm, 1937), Krasnoyarsk Area, Taymyrsky Dolgano-Nenetsky District, Taymyr Pen- 
insula, Lake Taymyr, Cape Blizhiy [13], spotted tundra, 9.VIII.1993, leg. A. Babenko.

REMARKS. In the Palearctic, the Arctic H. gertschi has hitherto been known from Wrangel Island [Eskov, 1985; Khruleva, 1987] and from the Kharaulakh Mountains, northern Yakutia [Tanasevitch, Nekhaeva, 2016]. This species is new to the fauna of the Taymyr Peninsula; Cape Blizhiy is the westernmost locality of the known species distribution.

RANGE. Siberian-Alaskan arctic.

\section{Hilaira glacialis (Thorell, 1871)}

MATERIAL. 1 ○', Krasnoyarsk Area, Taymyrsky DolganoNenetsky District, NW of Taymyr Peninsula, Ragozinka River flow [10], spotted tundra, 30.VII.1990, leg. Y. Chernov \& A. Babenko; 2 $\sigma^{\top} \sigma^{7}, 4$ $9 \circ$, Uboynaya River flow [11], spotted tundra, pitfall traps, VIII.1990, leg. Y. Chernov \& A. Babenko; 2 कo, Yakutia Republic, Yana River Delta, Shirokostan Peninsula, Lake Ledyanoye [16], undershrub tundra, 4-6.VIII.1994, leg. A. Babenko (R-68/94).

REMARKS. Lake Ledyanoye is the northernmost locality of the known species distribution in Yakutia.

RANGE. Siberian arcto-boreo-alpine.

\section{Hilaira incondita (L. Koch, 1879)}

MATERIAL. $2 \sigma^{\top} \sigma^{\top}, 5$ 우, Yamalo-Nenets Autonomous Okrug, Taz District, northern coast of Gydan Peninsula [8], seashore marsh with Carex subspathacea, Puccinellia phryganodes, pitfall traps, 13-18.VII.2016, leg. S. Rozenfeld.

REMARKS. In the Gydan, this species has recently been registered from the Yavay and Mammoth peninsulas [Tanasevitch, Khrisanova, 2016].

RANGE. Siberian-Nearctic arctic.

\section{Hilaira nivalis Holm, 1937}

MATERIAL. 1 \%, Yamalo-Nenets Autonomous Okrug, Kara Sea, Belyi Island [5], seashore marsh, pitfall traps, 26.VII.1.VIII.2016, leg. D. Nizovtsev; 1 ऽ, Yakutia Republic, Yana River Delta, Shirokostan Peninsula, Lake Ledyanoye [16], Eriophorum tundra, sweeping, 4-6.VIII.1994, leg. A. Babenko (R-67/94); 1 웅 East Siberian Sea coast, Omulyakhskaya Bay [19], 1985, leg. V. Bulavintsev \& N. Poryadina; 2 + , Indigirka River Delta, RusskoUstinskaya river branch [20], dwarf willow-sedge-moss swamp, under driftwood, 14-16.VII.1994, leg. A. Babenko (R-30/94); 1 क Kolyma Bay, Kolyma River Delta, Pokhodskaya Yedoma [21], under stones at foot of permafrost hummock, 18-19.VII.1994, leg. A. Babenko (R-48/94)

REMARKS. In the Gydan, this species has recently been registered from the Yavay and Mammoth peninsulas [Tanasevitch, Khrisanova, 2016].

RANGE. West Siberian arctic.

\section{Hilaira nubigena Hull, 1911}

MATERIAL. 1 ○', Arkhangelsk Area, Nenets Autonomous Okrug, Barents Sea, Kolguev Island, Lake Goltsovoe [1], dwarf willow-moss-lichen tundra with Rubus chamaemorus, pitfall traps, 27-28.VIII.1994, leg. A. Babenko (R-121/94); 1 \%, 2 우, same locality, wet meadow with Calamagrostis deschampsiodes, 2526.VIII.1994, leg. A. Babenko (R-117/94).

REMARKS. This is the first spider to be recorded from the Kolguev Island.

RANGE. European-Siberian-Alaskan arcto-boreal.

\section{Hilaira proletaria (L. Koch, 1879)}

MATERIAL. $1 \sigma^{7}$, Yamalo-Nenets Autonomous Okrug, Taz District, northern seacoast of Gydan Peninsula [8], seashore marsh with Carex subspathacea, Puccinellia phryganodes, pitfall traps, 13-18.VII.2016, leg. S. Rozenfeld.

REMARKS. In the Gydan, this species has recently been registered from the Yavay and Mammoth peninsulas [Tanasevitch, Khrisanova, 2016].

RANGE. Siberian-West Nearctic arctic.

Hybauchenidium aquilonare (L. Koch, 1879)

MATERIAL. 1 , Yakutia Republic, Laptev Sea coast, Olenyok Bay, Lake Vaganytta-Kyuel [15], permafrost hummocks on beach, Dryas communities with Salix polaris, 6-8.VII.1994, leg. A. Babenko (R-1/94); 2 ㅇ, same date and locality, Dryas communities on slope near snow patch, leg. A. Babenko (R-3/94).

REMARKS. Lake Vaganytta-Kyuel is the northernmost locality of the known species distribution in Yakutia's mainland.

RANGE. Siberian-West Nearctic arctic.

Hypselistes jacksoni (O. Pickard-Cambridge, 1902)

MATERIAL. 1 ', Yakutia Republic, Kolyma Bay, Kolyma River Delta, Pokhodskaya Yedoma [21], Eriophorum community on permafrost hummock, sweeping, 18-19.VII.1994, leg. A. Babenko (R-39/94).

REMARKS. In NE Yakutia, the species has hitherto been known from Malaya Konkovaya River flow [Marusik et al., 1993].

RANGE. Palaearctic-West Nearctic polyzonal.

\section{Masikia indistincta (Kulczyński, 1908)}

MATERIAL. 1 ๆ', Arkhangelsk Area, Nenets Autonomous Okrug, Vaygach Island, env. of Varnek Village [3], seashore, under driftwood, 25-26.VIII.1994, leg. A. Babenko (R-06/15); $27 \sigma^{7} \sigma^{7}$ \& $\rightarrow$, Yamalo-Nenets Autonomous Okrug, Taz District, Kara Sea, Belyi Island, seashore marsh, pitfall traps, 26.VII-1.VIII.2016, leg. D. Nizovtsev; $95 \sigma^{7} \sigma^{7} \&$ O+9, Taz District, northern seacoast of Gydan Peninsula [8], seashore marsh with Carex subspathacea, Puccinellia phryganodes, pitfall traps, 13-18.VII.2016, leg. S. Rozenfeld; 3 ○ $\sigma^{7} \& 8$ 8 , Taz District, Oleniy Island [7], seashore marsh with Carex subspathacea, Puccinellia phryganodes, rare: Cochlearia groenlandica, Hippurus tetraphyla, Senecio congestus, Eriophorum russeolum, pitfall traps, 13-18.VII.2016, leg. S. Rozenfeld; 2 우, Taymyrsky Dolgano-Nenetsky District, Taymyr Peninsula, Lake Taymyr, Ozhidaniya Bay [13], in snow patch, 25.VII.1993, leg. A. Babenko (L-21/93).

REMARKS. This species is new to the fauna of the Vaygach Island; Lake Taymyr in Taymyr Peninsula is the northernmost locality of the known species distribution.

RANGE. Siberian-Nearctic arctic.

\section{Mecynargus tundricola Eskov, 1988}

MATERIAL. 1 , Krasnoyarsk Area, Taymyrsky DolganoNenetsky District, NW of Taymyr Peninsula, Efremova River flow [9], spotted tundra, 22.VII.1990, leg. Y. Chernov \& A. Babenko; 1 +, northern seacoast of Taymyr Peninsula, Middendorff Bay, Opalovaya River flow [12], bank of river, under stones, 15-17.VIII.1994, leg. A. Babenko (R-97/94); 1 o, Taymyr Peninsula, Lake Taymyr, Ozhidaniya Bay [13], in snow patch, 24.VII.1993, leg. A. Babenko 
(L-21/93); 1 , , same locality, zonal type of tundra, pitfall traps, 29.VII.1993, leg. A. Babenko (L-36/93).

REMARKS. Lake Taymyr is the northernmost locality of the known species distribution.

RANGE. Siberian arctic.

Mughiphantes sobrius (Thorell, 1872)

MATERIAL. $1 \sigma^{\top}, 2$ o 2 , Yakutia Republic, East Siberian Sea coast, Indigirka River Delta, Russko-Ustinskaya river branch [20], dwarf willow-sedge-moss swamp, under driftwood, 14-16.VII.1994, leg. A. Babenko (R-30/94); 1 フ , 1 ㅇ, Yana River Delta, Shirokostan Peninsula, Lake Ledyanoye [16], undershrub tundra, 46.VIII.1994, leg. A. Babenko (R-68/94).

REMARKS. Lake Ledyanoye is the northernmost locality of the known species distribution in Yakutia.

RANGE. Palaearctic arctic.

\section{Oreoneta leviceps (L. Koch, 1879)}

MATERIAL. $1 \overbrace{}^{\Uparrow}, 2$ 우, Arkhangelsk Area, Nenets Autonomous Okrug, Malozemelskaya tundra, western coast of Pechora River Bay, env. of Lake Kuznetskoye [2], small-hummocky tundra, under driftwood, 25-26.VIII.1994, leg. A. Babenko (R-113/94); 1 , same date and locality, small-hummocky tundra, pitfall traps, leg. A. Babenko (R-118/94).

REMARKS. Lake Kuznetskoye is the northernmost locality of the known species distribution in the European mainland tundras.

RANGE. Siberian-Nearctic arctic.

Perro polaris (Eskov, 1986)

MATERIAL. 1 , Krasnoyarsk Area, Taymyrsky DolganoNenetsky District, Taymyr Peninsula, Lake Taymyr, Ozhidaniya Bay [13], in snow patch, pitfall traps, 22.VII.1993, leg. A. Babenko (L-27/93); 2 우, same locality, wet bare ground below snow patch, pitfall traps, 18.VII.1993, leg. A. Babenko (L-15/93).

REMARKS. In the Taymyr Peninsula, this species has hitherto been registered from Ragozinka River flow [Eskov, 1986]. Lake Taymyr is the northernmost locality of the known species distribution.

RANGE. Siberian-West Nearctic arcto-boreal.

Semljicola alticola (Holm, 1950)

MATERIAL. 1 ○', Yamalo-Nenets Autonomous Okrug, Taz District, Oleniy Island [7], seashore marsh with Carex subspathacea, Puccinellia phryganodes, rare: Cochlearia groenlandica, Hippurus tetraphyla, Senecio congestus, Eriophorum russeolum, pitfall traps, 13-18.VII.2016, leg. S. Rozenfeld; $1 \sigma^{7}$, Krasnoyarsk Area, Taymyrsky Dolgano-Nenetsky District, Taymyr Peninsula, Lake Taymyr, Ozhidaniya Bay [13], in snow patch, pitfall traps, 17.VII.1993, leg. A. Babenko (L-8/93).

REMARKS. This species is new to the fauna of the Taymyr Peninsula; Lake Taymyr is the northernmost locality of the known species distribution.

RANGE. Fennoscandian-Siberian arcto-boreal.

\section{Semljicola barbiger (L. Koch, 1879)}

MATERIAL. 1 , Arkhangelsk Area, Yamalo-Nenets Autonomous Okrug, Yugorsky Peninsula, Belyi Nos [4], peatbog hill in swamp, Rubus chamaemorus and Vaccinium vitis-idaea community, 8.VII.2015, leg. A. Babenko.
REMARKS. This species is registered from the Yugorsky Peninsula for the first time.

RANGE. Fennoscandian-Siberian arcto-boreo-montane.

\section{Semljicola simplex (Kulczyński, 1908)}

MATERIAL. 2 + 9 , Krasnoyarsk Area, Taymyrsky DolganoNenetsky District, Taymyr Peninsula, Lake Taymyr, Ozhidaniya Bay [13], bare ground below snow patch, pitfall traps, 18.VII.1993, leg. A. Babenko (L-15/93); 1 , same locality, in snow patch, 25.VII.1993, leg. A. Babenko (L-21/93); 1 \%, same date and locality, in snow patch, pitfall traps, leg. A. Babenko (L-40/93).

REMARKS. In the NW Taymyr Peninsula, this species has hitherto been registered from Ragozinka River flow [Eskov, 1985], and from the environs of Meduza Bay [Khruleva, 1999]. Lake Taymyr is the northernmost locality of the known species distribution.

RANGE. Siberian arcto-alpine.

\section{Tmeticus nigriceps (Kulczyński, 1916)}

MATERIAL. 1 ○', Arkhangelsk Area, Nenets Autonomous Okrug, Malozemelskaya tundra, western coast of Pechora River Bay, env. of Lake Kuznetskoye [2], small-hummocky tundra, under driftwood, 25-26.VIII.1994, leg. A. Babenko (R-113/94).

REMARKS. Pechora River Bay is the northernmost locality of the known species distribution in the European mainland tundras.

RANGE. Siberian arcto-montane.

Walckenaeria kochi (O. Pickard-Cambridge, 1872)

MATERIAL. 1 , Arkhangelsk Area, Nenets Autonomous Okrug, Malozemelskaya tundra, western coast of Pechora River Bay, env. of Lake Kuznetskoye [2], small-hummocky tundra, under driftwood, 25-26.VIII.1994, leg. A. Babenko (R-113/94).

REMARKS. Lake Kuznetskoye is the northernmost locality of the known species distribution in the European mainland tundras.

RANGE. Holarctic boreo-nemoral.

Wubanoides uralensis (Pakhorukov, 1981)

MATERIAL. 2 ㅇ, Krasnoyarsk Area, Taymyrsky DolganoNenetsky District, NW of Taymyr Peninsula, Efremova River flow [9], seagull colony on rocks, 20.VII.1990, leg. Y. Chernov \& A. Babenko.

REMARKS. This species is new to the fauna of the Taymyr Peninsula; Efremova River flow is the northernmost locality of the known species distribution.

RANGE. West \& South Siberian boreal.

Fam. Lycosidae

Alopecosa mutabilis (Kulczyński, 1908)

MATERIAL. 1 juv., Yakutia Republic, Yana River Delta, Shirokostan Peninsula, Lake Ledyanoye [16], dwarf willow-Dryassedge tundra communities on rock outcrops, 4-6.VIII.1994, leg. A. Babenko (R-72/94).

REMARKS. Lake Ledyanoye is the northernmost locality of the known species distribution in Yakutia. 
RANGE. Siberian-West Nearctic arctic.

Fam. Tetragnathidae

\section{Pachygnatha clercki Sundevall, 1823}

MATERIAL, 2 Oᄋ, Yamalo-Nenets Autonomous Okrug, Taz District, northern coast of Gydan Peninsula [8], seashore marsh with Carex subspathacea, Puccinellia phryganodes, pitfall traps, 13-18.VII.2016, leg. S. Rozenfeld.

REMARKS. In the Gydan, this species has recently been registered from the Yavay and Mammoth peninsulas [Tanasevitch, Khrisanova, 2016].

RANGE. Holarctic polyzonal.

ACKNOWLEDGEMENTS. I am greatly indebted to Anatoly B. Babenko (Moscow, Russia) and other persons whose collections have been used in the present study. Special thanks go to Sergei Golovatch (Moscow, Russia) who checked the English of an advanced draft. This study was supported in part by the Russian Foundation for Basic Research, projects \#15-04-05964 A, and \#16-44-890471 P_A.

\section{References}

Eskov K.Yu. 1985. [Spiders of the tundra zone of the USSR] // V.I. Ovcharenko (ed.). The fauna and ecology of spiders of the USSR. Trudy Zool. Inst. Akad. nauk SSSR, Leningrad. Vol.139. P.121-128 [in Russian].

Eskov K.Yu., Marusik Yu.M. 1994. New data on the taxonomy and faunistics of North Asian linyphiid spiders (Aranei Linyphiidae) // Arthropoda Selecta. Vol.2 (for 1993). No.4. P.41-79.

Khruleva O.A. 1987. [Invertebrates] // The flora and fauna of reserves of the USSR. Fauna of the "Wrangel Island" Reserve. Inst. Evol. Morphol. Ecol. Anim. Moscow. P.6-36 [in Russian].

Khruleva O.A. 1999. [Herpetobiotic Arthropods (Beetles and Spiders) of Northwestern Taimyr] // Striganova B.R. (ed.).
Problemy pochvennoi zoologii. Materialy II (XII) Vserossiyskogo soveshchaniya po pochvennoi zoologii. P.135136 [in Russian].

Marusik Yu.M., Eskov K.Yu., Kim J.P. 1992. A check list of spiders (Aranei) of Northeast Asia // Korean Arachnol. Vol.8. No.1/2. P.129-158.

Marusik Yu.M., Koponen S., Makarova O.L. 2016. A survey of spiders (Araneae) collected on the arctic island Dolgiy $\left(69^{\circ} 12^{`} \mathrm{~N}\right)$, Barents Sea // Arachnology. Vol.17. No.1. P.1024.

Marusik Yu.M., Eskov K.Yu. 2009. Spiders (Arachnida: Aranei) of the tundra zone of Russia // S.I. Golovatch, O.L. Makarova, A.B. Babenko, L.D. Penev (eds.). Species and communities in extreme environments. Festschrift towards 75 th anniversary and a laudatio in honour of Academician Yuri Ivanovich Chernov. Sofia-Moscow: Pensoft Publishers \& KMK Sci. Press. P.131-164.

Marusik Yu.M., Eskov K.Yu., Koponen S., Vinokurov N.N. 1993. A check-list of the spiders (Aranei) of Yakutia, Siberia // Arthropoda Selecta. Vol.2. No.2. P.63-79.

Matveeva N.V. 1998. [Zonation of Arctic Vegetation] // Trudy Botanicheskogo Instituta im. V.L. Komarova RAN. St.-Petersburg: Nauka Publ. 200 pp. [in Russian].

Osipov D.V. 2003. [Spider fauna (Aranei) of the southern tundra of the Western Taymyr] // Zool. zhurn. Vol.82. No.10. P.12661270 [Russian, English summary].

Tanasevitch A.V., Koponen S. 2007. Spiders of the southern tundra in the Russian Plain // Arthropoda Selecta. Vol.15. No.4. P.295-345.

Tanasevitch A.V., Nekhaeva A.A. 2016. Spiders (Aranei) of the Kharaulakh Mountains and the Lena River lower reaches, northern Yakutia, Russia // Arthropoda Selecta. Vol.25. No.3. P.307326.

Tanasevitch A.V., Rybalov L.B. 2010. On spiders from tundra zone of Kola Peninsula, Russia (Arachnida, Aranei) // Arthropoda Selecta. Vol.19. No.1. P.41-56.

Tanasevitch A.V., Rybalov L.B. 2015. Fauna and distribution of spiders (Aranei) of the arctic tundra in northern Yamal Peninsula, Russia // Arthropoda Selecta. Vol.24. No.2. P.215-230.

Responsible editor K.G. Mikhailov 